\title{
Modern Carriages for Heavy Naval Ordance
}

\section{Commander R. A. E. Scott R.N.}

To cite this article: Commander R. A. E. Scott R.N. (1866) Modern Carriages for Heavy Naval Ordance, Royal United Services Institution. Journal, 10:41, 496-516, DOI: 10.1080/03071846609416512

To link to this article: http://dx.doi.org/10.1080/03071846609416512

曲 Published online: 25 Sep 2009.

Submit your article to this journal $\pi$

Џ Article views: 1

Q View related articles $\sqsubset$ 


\title{
LECTURE,
}

Friday, 15th June, 1866.

\author{
QAptan E. GdRDINER FISHBOURNE, R.N., C.B., Vice-President, \\ in the Chair.
}

\section{MODERN CARRIAGES FOR HEAVY NAVAL ORDNANCE.}

\author{
By Commander R. A. E. Scotr, R.N.*
}

I APProicn the subject of the afternoon's lecture with some diffidence. I am not now about to adrocate a proposal which has yet to be tried, but I have principally to describe a success which has been already achiered. Tho necessary consequence of this is, that I shall appear to some to be sounding my own trumpet somewhat loudly; and I must therefore endearour, as far as possible, to let the facts which I shall lay before you speak for themselves. Still, I cannot forego the satisfaction of pointing out the opportunities which this Institution has afforded me of developing ideas which have since borne good fruit.

The importance of having such an areua for discussion as the theatre of the Royal United Service Institution, cannot be overrated, and I shall not bo blamed by the lovers of this Institution if I demonstrate clearly that some of the first steps towards the realisation of my projects for working henry guns ou a brondside, were taken in this room, and that in this room also both sides of the question were fairly and freely discussed.

In May, 1862, in the discussion which ensued on Captain Fishbourne's lecture on the best gun for naval warfare, Sir WV. Armstrong stated-" $A$ s regards present ships, naval men seem to bo agreed that " it is not possible to carry broadside guns much heavier than the "present 68-pr., or, at the veryi most, that six tons must be-the " limit."

In January, 1863, Mr. Barras gare here a lecture on the stability of ships in a seamay, and at that lecture I exhibited on the walls designs for a frigate and corrette, which were to be armed with 20-ton guns on the broadside, and the designs were accompanied by a table shewing the immense superiority of a few heavy guns over a number of small ones.

These diagrams and this table were again brought to your notice in March, 1863, on the occasion of Captain Arbuckle's lecture on iron forts and ships, at that officer's request, and the meeting wished me to explain them.

They are now again placed before you, that you may the more

- Now Captain Scott, R.N.-ED. 
Vot. 10.

P1. $X X x$.

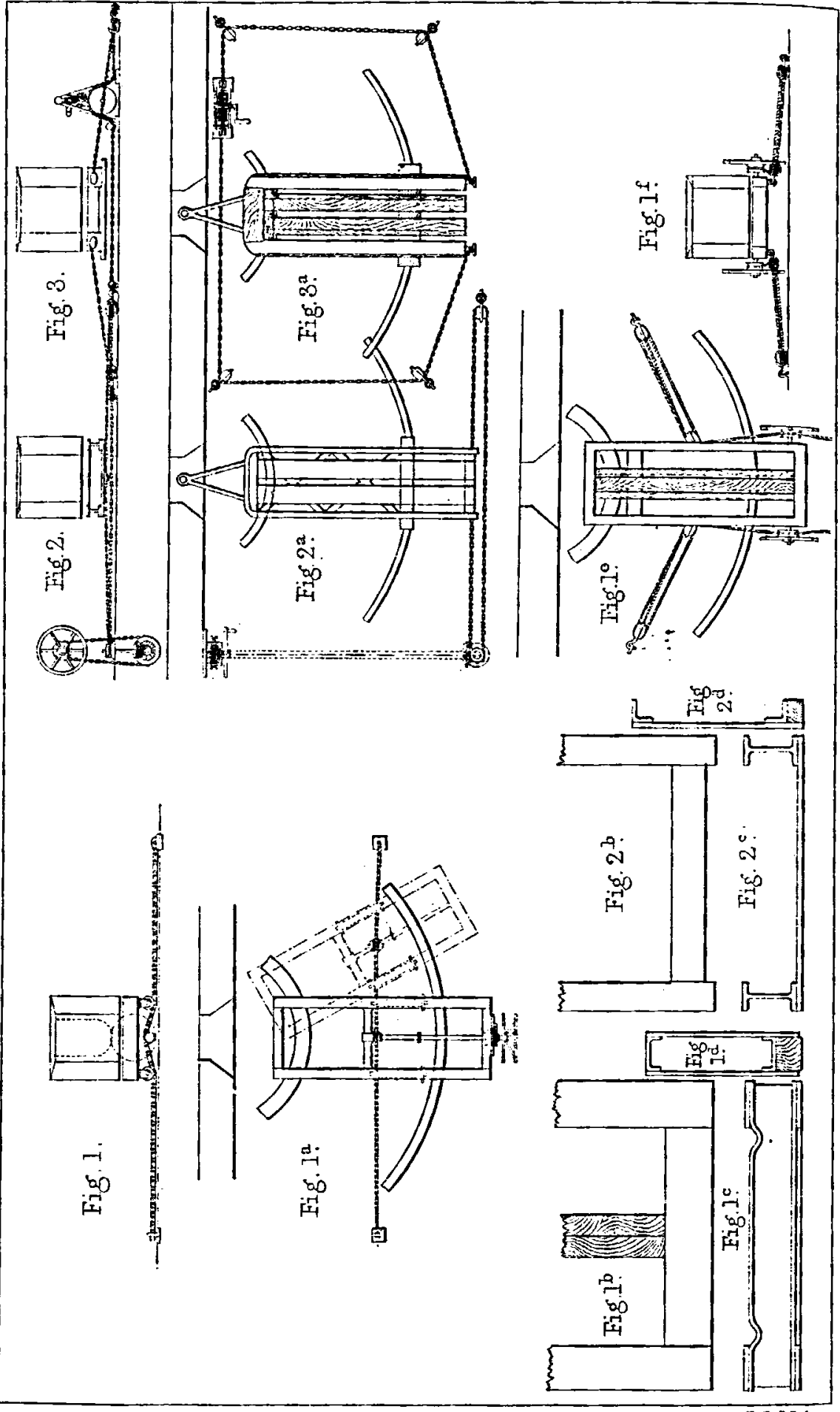



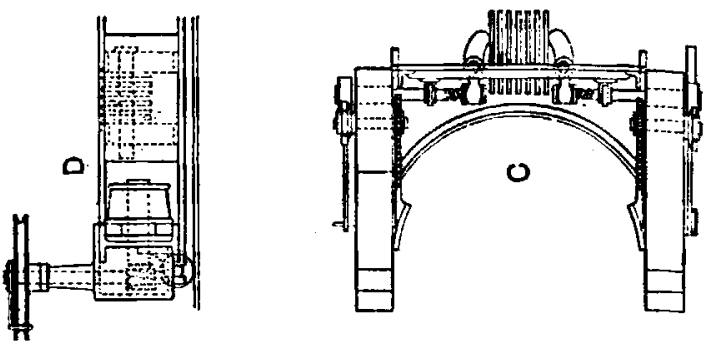

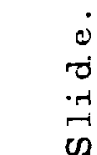

द

0

ज्ञ 0

0 के

ब H

ต.

$\rightarrow 0$

$\mapsto$

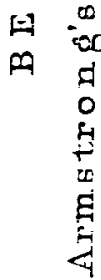
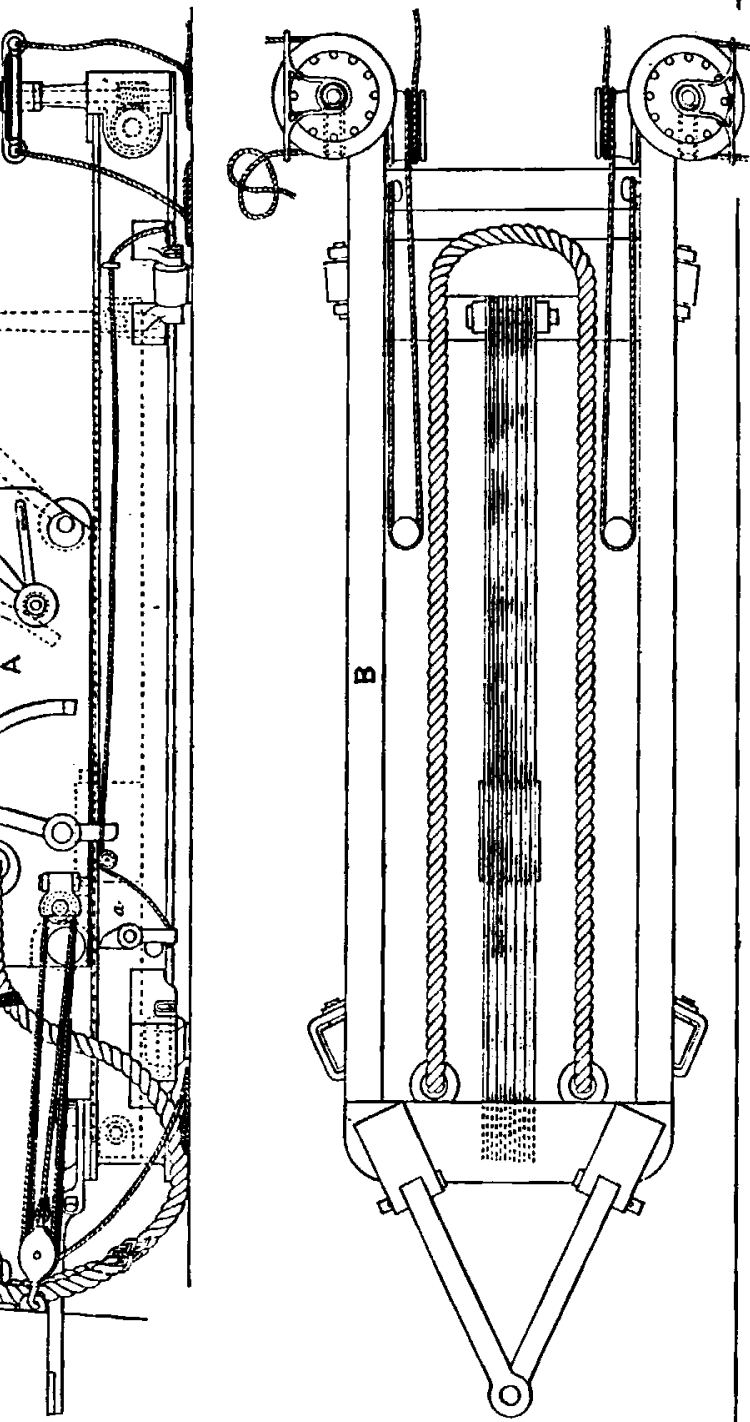
Fig. 1 .

BELIEROPHON.

C C Scott's 300 Pr Carriage and Slide. L $=$

3:
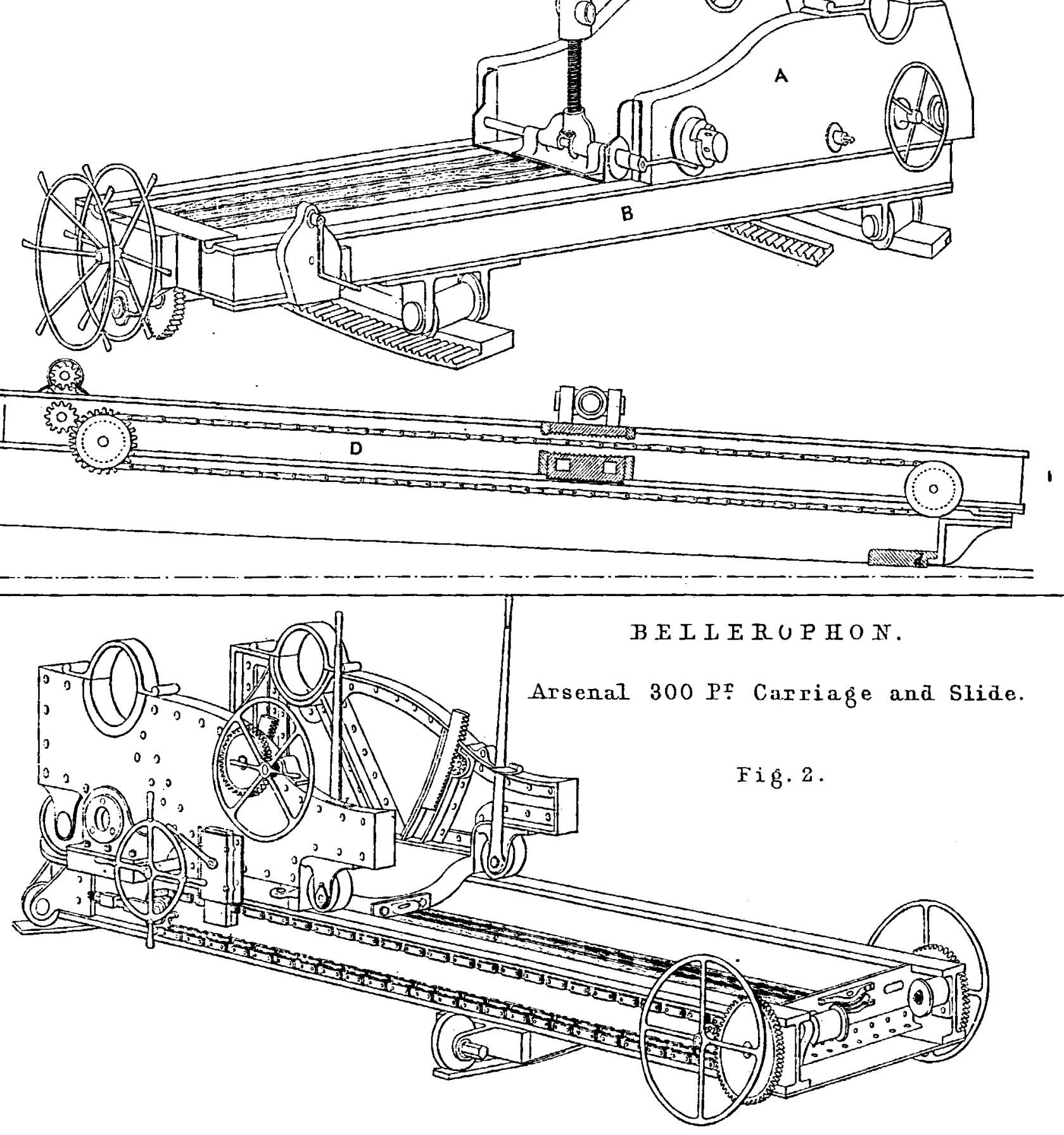


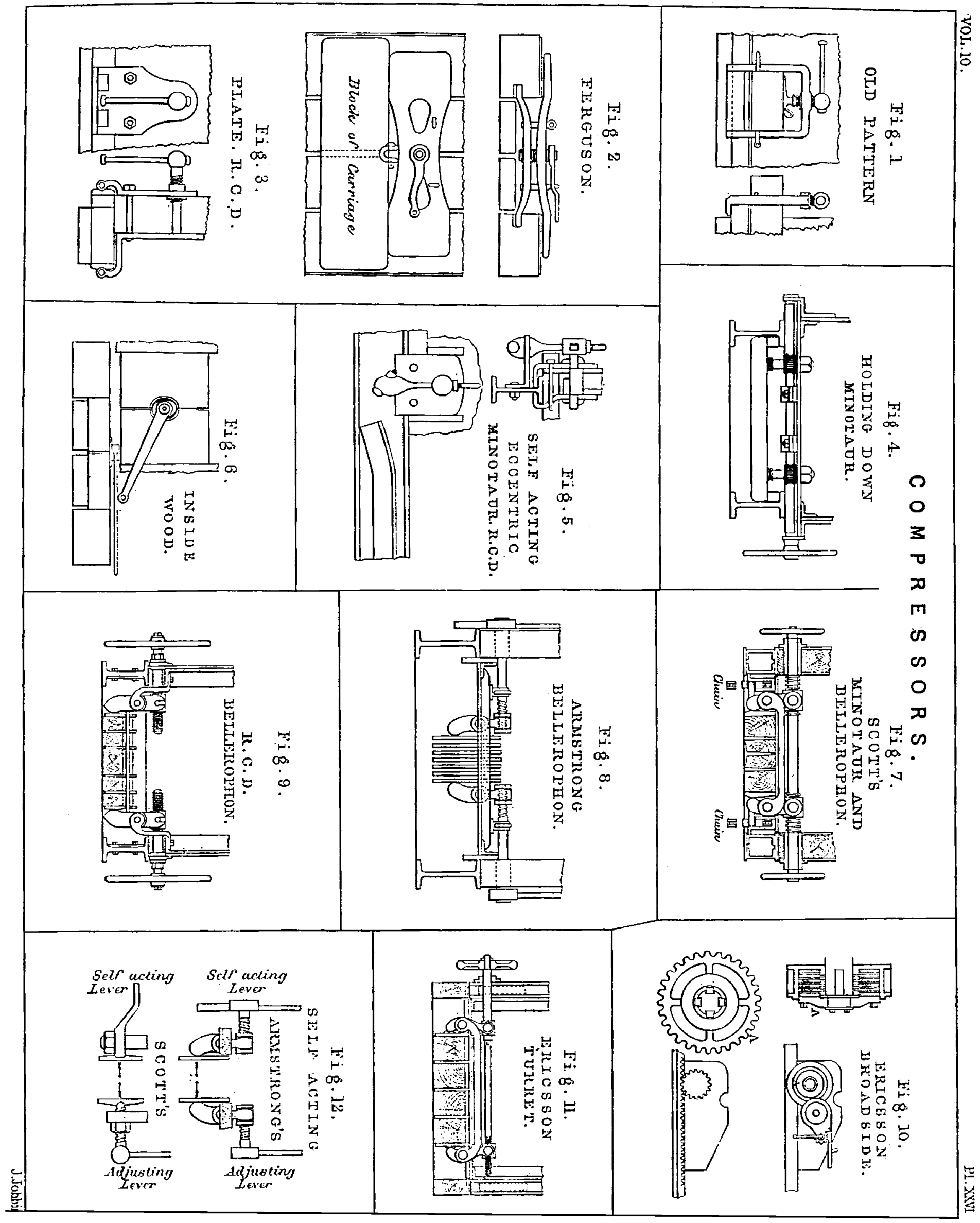




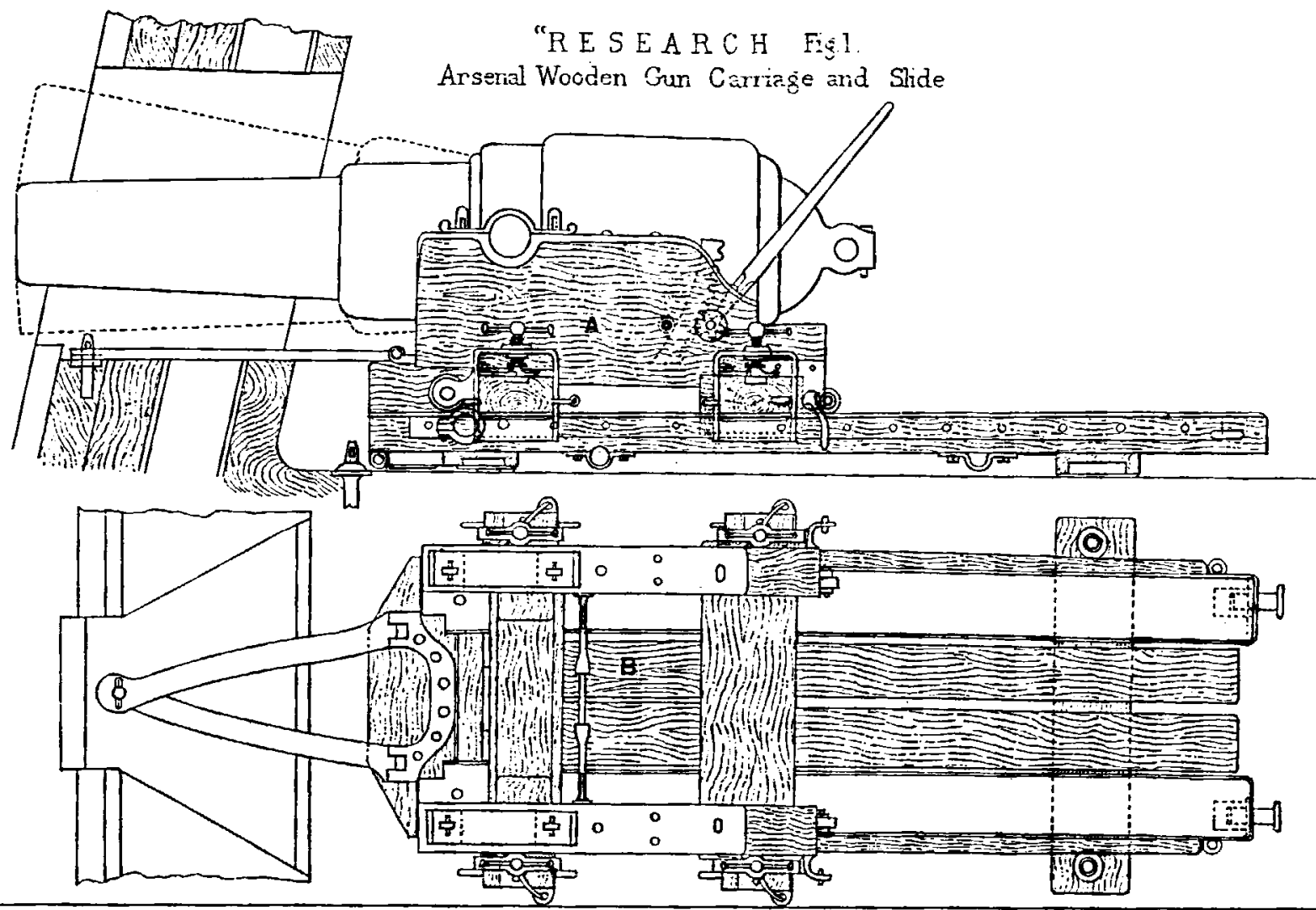

"R E S E A R C H. Fig 2 .

Iren Gun Carriage and Slide 100 Fr lifounted.
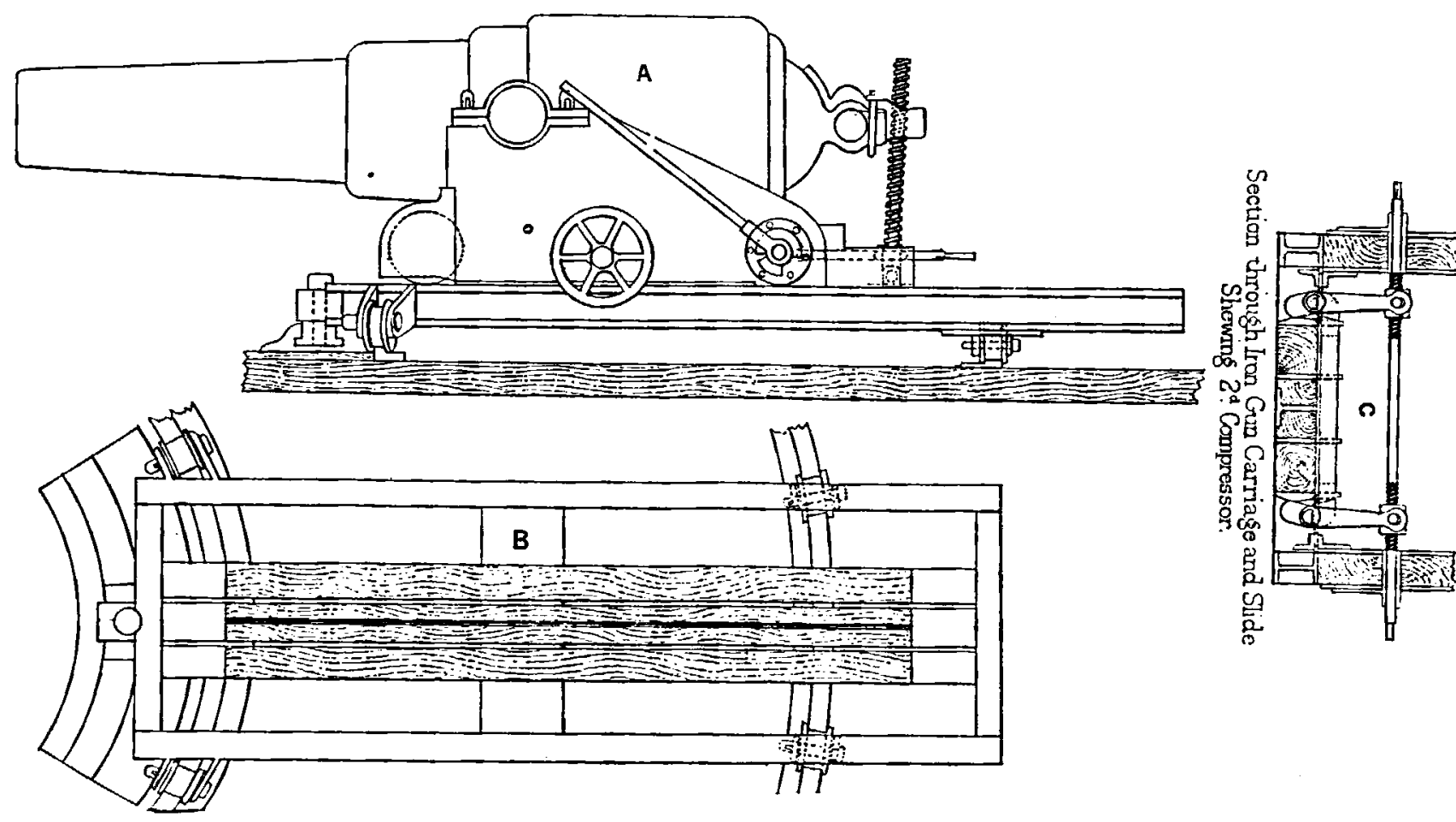


\section{MODERA CARRIAGES FOR HEAYY NAVAL ORDNANCE. 497}

readily follow the course which erents have taken as respects these proposals.

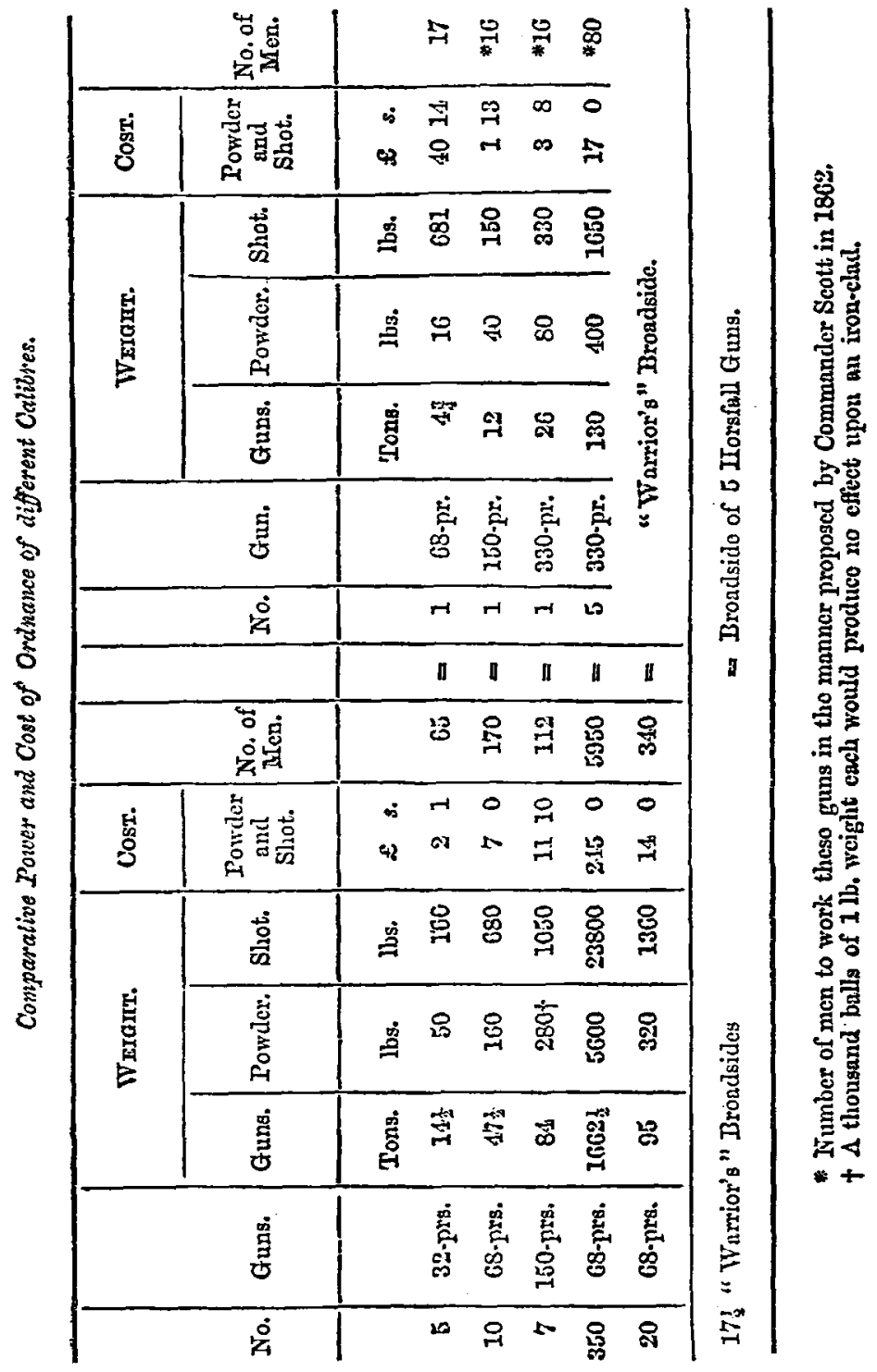

In February of the following year, viz., 1864, Mr. Cunninghan commenced his lecture before you with this question- "Can we continue to 
work our heary guns by manual power?" and he decides the question in the negative. ITe thinks that "arms of flesh and bone must givo way" to the iron arms and sinerrs of the mighty steam-engine," and that though 12-ton guns may be worked by 21 men on a level battery deck, he doubts whether half as many again would be able to control such ponderous guns at sea. "One word," he adds, "more on this point." "It has often been remarked to mo by offcers, that they always " dreaded casting loose their 68-prs. at sea, and were alwass delighted "when the guns were again secured. If, thon, this anxiety cxisted " in regard to guns of "betwcen four or five tons in weight, how great " must it be, or rather will be, when dealing with guns three times " heavier, with probably alt the cmbarrassing accompaniments of wet, "slippery decks." (Sce Journal Royal United Serrice-Institution, vol. viii, page 70.)

In Aay, 1865, the Turret Committec sat, and Captain. Preedy, in answer to Captain Kennedy's question--Can you imagine any possible way of fighting a 12-ton gun except in a"turret? replied "No."

Gaptain IIornby stated before the same Committec that Captain Willes, having cast a 61-ton gun adrift in a seaway (that is to say, having remored the lashings, ready for working), the gun was unmanageable, and tho men were afraid to go near it. The slide also was damaged in firing the gun.

Still, at this time, the views of men were undergoing some change, for,-through the assistance of the Admiralty, I-had made a slide and carriage for a $6 \frac{1}{4}$-ton gun, to which I shall have again to refer. It is represented in diagram, Fig. 2, plate $\mathrm{xxv}$, aud my confidence in its success was beginning to have weight.

Captain Meath, for instance, thinks, in the same month, when questioned by the Turret Committec, that a 12-ton gun ought long ago to have been tried in tho Channel squadron, and considers that the danger most to be apprehended will be the running-out of the gun.

Captain Key also hopes, at this time, that wo shall be able to work the 12-ton gun with 16 men, but expresses similar fears concerning the ruming in and out; and Captain Preedy, who had commanded the Irector, one of the iron-clads of the channel squadron, informed the Committee that " the other day wo had great difficulty in running the "gun in with 22 men on tho train whips and tackles attached to the "carriage, the ship only hecling over six degrees; but the fact of "firing the gun I have no doubt would hare brought it in. Why I "alluded to running-in was this, the ports of these iron ships are low, " and if you get a gun out and cannot get it in arain, it would be a "very serious matter in a seaway, for you would ship such heavy seas "that it would become a very serious matter."

And Captain IIornby, in concluding his evidence, gave a very similar opinion.

It will be seen from all this that; though we now talk familiarly of working 12-ton guns in a seaway, it is only very recently that the most sanguine, timidly hoped to accomplish the task, and the less hopeful, who had'seen. the 68-prs. in a seaway,. looked at by the sailors from a distance like some savage animal dangerons to approach, pronounced it an impossibility. 
The month after this evidence was given my, carriage and slide for a 61 titon gun wero placed. in the "Research." I desired that they should be prepared for a 12-ton gun at onco. I. said in my official letter of February 4th, 1864- "I feel-suro that the 12-ton guns could " by this method be worked in a seaway with greater ease and safety "than 68-prs. mounted upon tho old principle." The Admiralty, however, cautiously, and perhaps more wisely, in the face of such doubts and fears on the part of many experienced and able Officers, cognizant alone of the old system of working guns, restricted my first experiment to a carriago of the smaller size.

Now here I wish to call your attention especially to Captain Preedy's evidence, just quoted. IIe speaks of the danger and difficulty which had been experienced in working a $6 \frac{1}{4}$-ton gun in a seaway, and in a lieel of only six degrees, with 22 men. IIe is so impressed with this danger and difficulty, that he. would not go an ounce orer a 6 -ton gun for the broadside, and yet in the rery next month, my carriage and slide for a $6 \frac{1}{4}$-ton gun were worked in a roll of seven degrees with 9 . men-quick firing, with the greatest case and safety.

Previous to this, the Admiralty had given-authority for the com: mencement of the 12-ton gun-carriage and slide. They had seen the 61-ton gun-carriage and slide in Woolwich Dockyard carly in 1865, and felt justified in authorizing the further.expenditure. The arrange: ments for experimenting with the larger carriage and slide were not, however, completed until the latter part of last year, when they were put on board the "Mlinotaur:"

It is necessary, horever, that I should here retrace my steps. My course was not so easy and pleasant as may have appeared from my correspondence with my Lords of the Admiralty.

By existing regulations and arrangements, the Nary does not make its own carriages and slides, any more than design its own guns.

$\mathrm{MI}$ proposals were, in regular course, submitted to the War -Department, and the officers of that department having had the advantage of my plans and sceing that I had introduced the word "American," in reference to the uso of compressors in turrets, thought that it would be better to improve on what they chose to consider this "American" notion to giving a trial to my system in its integrity. I trust you will pardon my being a little bitter here. I don't like the system of improrement on other people's idens by Committees appointed to test the value of inventions, and I believe it will generally be found to lead to what happened in this case.

Aly carriage and slide when thus improved upon, but with some of its most important features omitted, was sent to the "Excellent" for trial, and the report on them was- "that the compressor did not act, though, to all outward appearance, in working order ; and on January 29 th, during practice, without the least warning, ceased to act,"-" that no safe conclusion can be dramn from experience in the United States, as their guns are heavy and fired with low charges"-and that "this form of compressor had been abandoned in the American nary."

On the communication to me of this report, I called attention to the fact, that it was not my notion which had been tricd, but the American notion, improved upon by a Committee; and thereupon orders were given 
that I should carry out my own notion in my own way, in Her Majesty's Dockyard; and whon I have concluded my history of the broadside 12-tonners, I think you will agree with me, that it was at least a step towards the solution of the problem.

My carriage and slide for a $6 \frac{1}{4}$-ton gun were made, and proved successful, beating the improved Arsenal carriage with its new platecompressor and eccentrics as well as the then service-pattern carriage (Plate xxv, fig. 1) on every point, as seen by the following records of the firing:-

No. 1.

Report of firisg mith Captati Scott's and Otd Patters Woodex Cag. RIAGE, JUNE $2 \mathrm{ND}, 1865$.

Guns pointed at a ship at a distance.

No. of crem (Scott)..... 9

Do. mooden carriage.... 19

\begin{tabular}{|c|c|c|c|}
\hline \multirow{2}{*}{ Rounds. } & \multicolumn{2}{|c|}{ Times. } & \multirow{2}{*}{ Remarks. } \\
\hline & $\begin{array}{l}\text { Captain } \\
\text { Scott's. }\end{array}$ & $\begin{array}{l}\text { Old rooden } \\
\text { carriage. }\end{array}$ & \\
\hline$\frac{1}{2}$ & $\begin{array}{ll}\mathrm{m} . & \mathrm{s} . \\
\ddot{1} & \ddot{00}\end{array}$ & $\begin{array}{ll}\text { m. } & \text { s. } \\
\ddot{1} & 33\end{array}$ & $\begin{array}{l}\text { Both guns single shot. } 20 \mathrm{lb} \text {. charge. } 2^{\circ} \text { ele. } \\
\text { ration. }\end{array}$ \\
\hline 3 & $0 \quad 43$ & 125 & $\begin{array}{l}\text { Captain Scott's carriage. 14 rounds in } \\
\text { 11m. 32s. }\end{array}$ \\
\hline 4 & 056 & 122 & $\begin{array}{l}\text { Old wooden carriage. } 10 \text { rounds in } \\
\text { 11m. } 07 \mathrm{~s} .\end{array}$ \\
\hline 1 & $" n$ & $" \quad "$ & $\begin{array}{l}\text { Captain Scott's carriage. Rear compressor just } \\
\text { touching ; fore compressor not used. Recoil } \\
\text { to a modcrately taut brecehing each time. }\end{array}$ \\
\hline $\begin{array}{l}2 \\
3 \\
4\end{array}$ & $\begin{array}{ll}0 & 40 \\
0 & 59 \\
0 & 53\end{array}$ & $\begin{array}{ll}1 & 01 \\
1 & 03 \\
1 & 38\end{array}$ & $\begin{array}{l}\text { Old rooden carriage. Right rear compressor } \\
\text { carried aray. Slide rery much injured. } \\
\text { Left rectangular pirot bar cracked acros } \\
\text { the hinge. }\end{array}$ \\
\hline \multirow[t]{2}{*}{$\begin{array}{r}5 \\
6 \\
7 \\
8 \\
9 \\
10 \\
11 \\
12 \\
13 \\
14\end{array}$} & $\begin{array}{ll}1 & 10^{*} \\
1 & 00^{*} \\
0 & 45 \\
0 & 53 \\
0 & 50 \\
0 & 51 \\
0 & 50 \\
0 & 49 \\
1 & 02^{*} \\
0 & 49\end{array}$ & $\begin{array}{ll}1 & 18 \\
1 & 11 \\
1 & 03 \\
1 & 03 \\
1 & 28 \\
1 & 22\end{array}$ & \\
\hline & 1132 & $11 \quad 07$ & \\
\hline
\end{tabular}

- In these rounds trigger line came unlooked, causing mis.fire. 
No. 2.

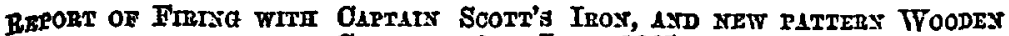
CLRRIAGE, 3ed JUNE, 1865.

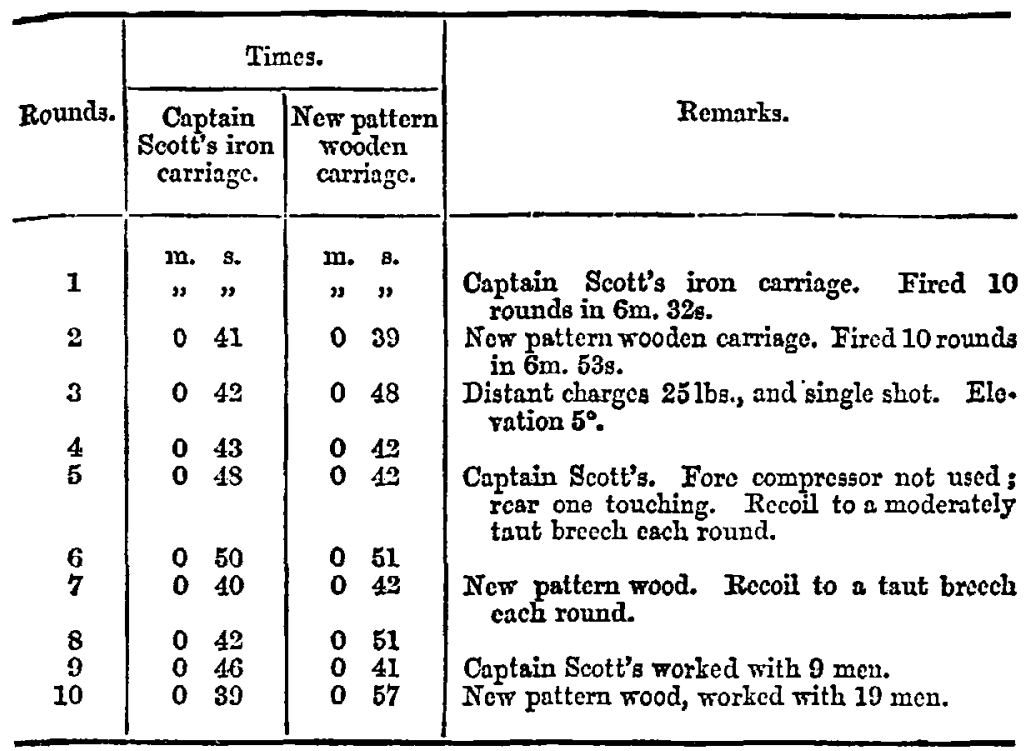

Besides tho successful issue of this competition with the improred carriage, specially prepared to compete with mine, I had the further satisfaction to find that both tho Officers of the ship, and the men who worked the guns were equally in favour of the wrought-iron carriage. The crews of the guns mounted upon the improved and upon the service-pattern carriages, ascribed their defeat to the superiority of the iron carriage, and wished to be allowed to work it in turn with its proper crew.

Subsequent to these trials, some of which are recorded in tables 1 and 2, further experimental firing, from the same carriages, took place at Portland and was thus reported upon:- "Judging, however, from the performance of Commander Scott's carriage, at anchor and in smooth water, I think its superiority over the other carriages in its indestructibility, power of control, training, elevating, and the smallness of its crew (9 instead of 19), is very manifest.

"All the wooden carriages exhibit, in a greater or less degree, symptoms of weakness, whereas Commander Scott's eems to improve by use."

The final report of October, 1865 , stated that the simplicity of the moving parts of Scott's carriage has caused the carriage and slide to be worked with perfect confidence by the men, and that the carriage 
and slide possessed the special advantage of doing amay with the necessity for the usual long and harassing drill.

In the meanwhile the plate-compressor and eccentrics were adopted, and; at the same time, the rear racer, which formed part of my plan. The front rollers on the slide; which-had been shown in my drawing of February, .1864, and which were described in this theatrc on $\mathrm{M}$ arch 2nd, 1863 (sec Royal United Service Journal, vol. vii, page 92), were adopted for broadside slides on September 3rd, 1864, and the slide was of a somewhat similar pattern to that shown in Fig. 1, plate xxv, except that eccentrics were applied to its rear rollers for training. The plate-compressor is shown in Fig. 3, plate xuri, under the liead of compressors.

The improved caniage which competed with mine, and to which this compressor was affised, is somewhat similar to the service carriage shown in Fig. 1, plate xxr.

The state of the gua-carriage question and the improrement made during late years in the mode of working guns, will be more clearly shown by a slight sketch of the past, up to the dato of my first competition in the "Research."

A compressor (Fig. 2, plate axri), called Ferguson's, had been in use since 1858, but does not seem to lave latterly given very satisfactory results, for we find that in $\Lambda$ ugust, 1863, the Ordnance Select Committee state, that the charge of the 9 -inch smooth-bored gun " had to be reduced" from the 33 lbs., proposed by $\mathrm{Sir}^{\mathrm{W}} \mathrm{W}$. Armstrong, "to $25 \mathrm{lbs}$, on account of the iecoil," and thes add, "that wrouglit-iron guns might be made-lighter than they are, or be used with heavier charges, if $r$ the recoil could be more effectually checked."

And in the same Committee's report of the previous month, it is stated in respect to this 100-pr. smooth-bore, that " $\mathrm{Sir}$ WV. Armstrong" originally contemplated a charge of $33 \mathrm{lbs}$, with. which 80 rounds were fired without apparent injury to the gat, but this sharge prored too great for the carriage, which broke three times under it. On one occasion, when fired on a naval slide and carriage with this charge, Ferguson's compressor and an insido compressor (Fig. 6, plate axvi) licing used, it recoiled 6 fect off tho slide."

That the need of. a good compressor was urgently felt and could, not Ze obtained, is clear, for at the end of July, 1863, Sir W. Armstrong, in answer: to the Committee's enquiry, states, that " "he is not prepared with any plan of compressors for more effectually, controlling recoil."

I think I have now shown that not only was there no good naval carriage, but that its want had occasioned the charge of the 100-pr. to be reduced below efficiency, viz., from $33 \mathrm{lbs}$. to $.25 \mathrm{lbs}$. This charge lessened the initial velocity of its shot more than 200 feet per second; and as a reduction to a $20 \mathrm{lb}$. charge was in prospect, with a proportionate diminution in the charge of the 12-ton guns, I thought that at last there was surely a "rowlock" for a seaman's oar; and hence, at the end of $1563, \mathrm{my}$ propositions of 1862 , with respect to the mounting of very heavy guns, were again brought forward and submitted to the naval authorities: With the results of that submission you hare already been made acquainted. Shortly before my drawiugs had been sent 
forward, an attempt was made to supply the want of a good broadside carriage. The result was the spider or Jim Crow cariage, which proved, howerer, far too nimble for poor Jack's safety, and has since been denvered into a land serrice mounting:

Ft is now, howerer, necessary to describe the compressor which fellowed the Ferguson's, and also the plate compressor wlich was' recommen'ded to be adopted for all slides in July,' 1865 , only one moath after its first trial against my compressor in the "Tesearch."

In the ofld-system of slide carriages for revolving guns, two compressors were applied for the 68 -prs.; bat when the 100-pr. smooth bore, firing a larger charge, was introduced into the scrvice as a broatdwide gun, another compressoi was added on each side of the carriage, máking four compressors, as 'shewn' in:Fig. 1, plate'xxr. 'These could 'not 'possibly' be tightened-akike, and 'hence 'there was grẹat chance of tbat which bore the most strain being carried away.

This frequently happened, and at 'best these compressors are very difficult to manage, and uncertain in action. An inside compressor (Fig. 6, plate xxri) was then introduced as an auxiliary, making firc. separnte compressors, requiring five men to work then These compressors wcre used in 186t on both the 100-pr. and 12-ton gull-carriages (sec Figs. 1 and 6 , plate xxvi), but were being gradually displaced by the plate compressor towards the end of 1865 ; but the chargo of the 100-pr: has not been increased.

The competition in the "Research", and" the labours of the "Turret Conmittee, secmed to have turned public attention to the improrement of gun mounting; for now' I had competitors for the 12-ton g"un-carriage and slide. I worked at my single carriage and slide in Woolwich dockjard, and the committee worked at their.various ones in the Royal Arsenal at the same time.

I will now describe how these systems turned out when tried in the "Minotaur." But first let mo gire you some of tho particulars of my competitors' plans, which will hereafter be more particularly described:-

1. The Arsenal wrought-iron carringe and slide.

2. The improved pattern, wooden carriage and slide.

3. Another improred pattern, wooden carriage and slide.

1. The Wrought Iron Carriage and Slide.-To this was affixed, 1st, the plate compressor, which was remored before trial; then a holding-down compressor (Fig. 4, plato xxvi), which broke down after a for discharges, allowing the gun to recoil nearly clear of the slide. 3rdly, a self-acting compressor (Fig: 5), which entirely failed. This mounting was trained by.tackles.

2. The Improved Pattern.-This was fitted with the plate compressor, which failed to arrest the gun, and left great part of the recoil to be checked by the'breching. The training was done by Mr. Cunninghan's chain'gearing (in 'Yeu of the winches previously usod on board the "Minotanr"), and single chains were, immediately precoding the trial, put on by Mr. Cunningham to run the, gun in, and out.

3. This carriage was provided with a new arrangement of elevating gear, and had a rilled gun mounted upon it. The self-acting com- 
pressor of new pattern fitted to it, proved a failure; and hence tapering the sides of the slides, in imitation of my wooden baulks, was resorted to, but without success.

The competition was thus ended by the failure of the compressors, and of the other gear which competed with mine. The iron slide of the Arsenal gun was found to hare become bent. During the trials which took place a short time previously in the "Minotaur" with a 12-ton gun, mounted upon an improved wooden carriage and slide, the quickest firing obtained was ten rounds in $11^{\prime} 7^{\prime \prime}$. and this was considered remarkably quick, being much faster than the firing from a similar gun in a turret.

With Scott's carringo and slide, and a crew that had never worked together before being sent to the "Minotaur," or had erer scen a 12ton gun fired, the first ten rounds that were fired were completed on

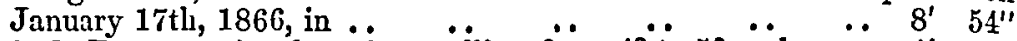
2nd. Four rounds, slow time, rolling from $4^{\circ}$ to $5^{\circ}$ cach way $4^{\prime} 20^{\prime \prime}$

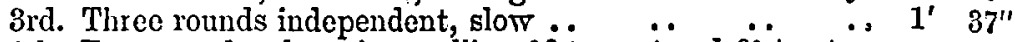
4th. Four rounds, slow time, rolling $8^{\circ}$ to port and $6^{\circ}$ to star-

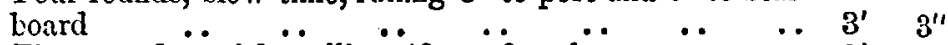
5th. Five rounds, quick, rolling $4^{\circ}$ to $\ddot{5}^{\circ}$ cach way $\ldots \ldots \ldots 3^{\prime} \quad \ldots 0^{\prime \prime}$ Gth. Ten rounds, quick...

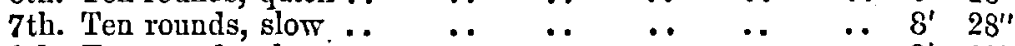

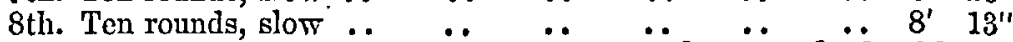

On January 18 th (the next day) some rounds were fired with the gun double-shotted, with the full 40 lbs. charge, but although only one compressor was used, the gun did not recoil to a taut breeching. The quickest firing on this day was-

$\begin{array}{lllll}\text { Ten rounds, quicls, in } & \ldots & \ldots & 5^{\prime} & \mathbf{5 8} \\ \text { Twelve rounds, quick, in } & \ldots & \ldots & 6^{\prime} & \mathbf{3 2}\end{array}$

On February 2nd; the third day's trial, full $40 \mathrm{lb}$. charges being still used, the firing was as follows:-

1st. Ten rounds, quick, in .. $\quad \ldots \quad 5^{\prime} \quad 45^{\prime \prime}$

2nd. do. do. $\ldots$...

$\begin{array}{llllll}\text { 3rd. do. do. } & \ldots & \ldots & 4^{\prime} & 48^{\prime \prime}\end{array}$

Men changed rounds twice, same captain of gun retained.

$\begin{array}{lllllr}\text { 4th. Ten rounds, quick, in. . } & \ldots & 5^{\prime} & 58^{\prime \prime} \\ \text { 5th. do. } & \text { do. } & . & \ldots & 5^{\prime} & 25^{\prime \prime} \\ \text { 6th. do. } & \text { do. } & . . & \ldots & 5^{\prime} & 13^{\prime \prime} \\ \text { 7th. do. } & \text { do. } & . . & \ldots & 5^{\prime} & 1^{\prime \prime}\end{array}$

The final trial-the other gun-carriages being hors de combatwas to test the strength of Scott's racers, and the power of his compressors, by firing the gun at the top or sharpest part of the roll. The front pirot-block was let go, and the hook under the front racer slack, so that the whole shock, \&c., was taken by the racers only. The firing of 19 rounds was as follows, with only one compressor, and breeching never taut:- 


\begin{tabular}{|c|c|c|c|c|}
\hline 1st. & rolle & & & \\
\hline 2nd. & do. & $\begin{array}{l}\text { sum nred at } \\
\text { do. }\end{array}$ & $\because$ & $4^{2 \frac{1}{2}}$ \\
\hline 3rd. & do. & do. & 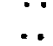 & $2^{\circ}$ \\
\hline 4th. & do. & do. & $\therefore$ & $4^{\circ}$ \\
\hline oth. & do. & do. & . & $1^{\circ}$ \\
\hline 6th. & do. & do. & .. & $5^{\circ}$ \\
\hline 7th. & do. & do. & .. & $7^{10}$ \\
\hline 8th. & do. & do. & . & 37 \\
\hline 9th. & do. & do. & .. & $2^{\overline{0}}$ \\
\hline 10th. & do. & do. & . & (?) \\
\hline 11th. & do. & do. & . & 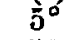 \\
\hline 12th. & do. & do. & . & $50 \frac{1}{2}$ \\
\hline 13th. & do. & do. & .. & $6^{\circ}$ \\
\hline 14th. & do. & do. & . & $6 \frac{1}{2}^{\circ}$ \\
\hline 15th. & do. & do. & .. & $10 \frac{1}{2}$ \\
\hline 16th. & do. & do. & .. & $7^{\frac{b}{0}}$ \\
\hline 17th. & do. & do. & . & $6 x$ \\
\hline 18th. & do. & do. & . & $10^{\circ}$ \\
\hline 19th. & do. & do. & & $5^{\circ}$ \\
\hline
\end{tabular}

The result astonished every one, and it was publicly stated by tho Officer who conducted the experiments, that Commander Scott's carriage had come out "most triumphantly." And it was then recommended that some form of the American compressor should be adopted, which, judging from the carriages subscquontly made, seems to have meant that the features of Scott's compressor, with its doublo action and lever arms, and its frictional surfaces which had been so carefully worked out and so successfully applied to slides, should be imitated.

The question was now settled; there seemed no room for another invention; but still the opportunity was tempting. People may ask the question, "What's in a name"-but there is a good deal in a name. Commander Scott's name, for instance, does not command the same attention as Sir W. Armstrong's. Think of the figure I should hare cut if Sir William Armstrong had been the first to devise the method of working heavy guns in a sea-way, and I had pretended to improve upon his idea! But Sir W. Armstrong's modifications upon my carriage and slide were at once received as undeniable improvements.

These modifications were the substitution of iron for wooden baulks and an inside breeching of rope to stop recoil, in lieu of the gradually tapered baulks of wood to absorb it. Sir William further added to my plan of compressor a self-acting arrangement, differing little from that proposed by me in 1864 (See Fig. 12, plate xxvi), and in place of my endless chains for running the gun in and out, applied a rope (Figs. A and B, plate $x \times$ viii).*

Sir William's elerating gear was similar to that first introduced by the carriage department, but far more strongly and better made; and his carriage was of the box-girder construction.

The Armstrong slido was of double T-iron, admirably rolled, and was fitted with the new eccentrics.

* The proportions in this plate are smallor than those in Plate srrii,-Ko. 
This slide worked upon two racers, and had a third laid down to support its front.

The Arsenal also sent a slide of double T-iron, fitted with my running-in and -out chains, slightly modified, and fitted with fire wooden baulks of smaller dimensions than mine. The compressor was also similar, but weaker, and the shaft was cut into two parts, which further reduced its strength.

In the carriage, the single-sided construction was adhered to, but the clerating gear was fitted with a wheel on one side in order to attain that nicety of aim which was found to be impracticablo with lerer handspikes, whose jerky and uncertain action, the eyo could not follow.

The times of firing were as follows:-

Scotts's quickest 10 rounds, $10^{\prime} 45^{\prime \prime}$; other 10 rounds, '11' $25^{\prime \prime}$. Armstrong's do. 13' $21^{\prime \prime}$; do. $15^{\prime} 32^{\prime \prime}$. Ar'senàl do. $15^{\prime} 41^{\prime \prime}$; do. gearing brokc.

In the "Minotaur," ten rounds were fired from Scott's gun-carriage in $4^{\prime} 48^{\prime \prime}$, and deducting the extra time alike required for loading all the guns with heary, clongated shot, viz., 6 minutes, the relative times of performing the other operations would be :-

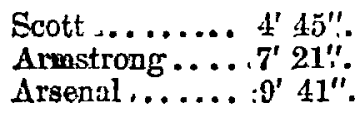

These figures may therefore be fairly taken as represeriting the comparative facility afforded by.each of the gun-carringes, for working them.

Unfortunately, the weather was too fine to fully derelope the advantages which were so apparent in my mounting, when there was any motion in the "Minotaur;" and hence the competition was closed without any trial of firing in rolling or at the top of the roll. Such a trial would have afforded conclusive evidence as to the holding power of Armstrong's modified iron-compressor, and proved, in some mensure at least, whether Professor Airy's demonstration of the intensity of the shock of one hard metal jarring against another, is borne out by practice...In facility and quickness of training by tackles, Scott's gun-carriage had a great advantage over both its competitors; and in running the gun in aud out its gear performed the operation in

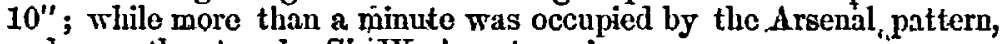
nnd more than two by Sir W. Armstrong's.

MIy elevating gear moved the gun with great steadiness, and quite ns fast as the eye could follow, and, as it never ran dowp, the clevation was almays, certain in quick firing.

My gun liad a preponderance of $6 \mathrm{cwt}$. in the breech; the two other rguns had no preponderance, though how such guns can bo elevated or depressed by quoins, if the gear be damaged, is a difficulty not yet solved.

The gun upan!myi mounting was several timies.fired with its muzzlo 
above the port, without injury to the clevating screw; but a further description of the mode of working will bo found at the end of this paper. It is therefore only necessary to mention in this pläce, that with the shortest of these competitive slides the muzzle of my gun was a foot further outside the port, than the muzzles of either of the other guns, and that the arrangement of my racers, \&c., while affording greater training with a smaller port, assisted in prerenting so heary a jar, as was noticed on the discharge of the guns mounted upon the Armstrong and Arsenal carriages. Behind tho latter, the deck was in fact pressed down one-quarter inch by the shock.

The compctition was concluded after 60 rounds from the Armstrong and Arsenal gun-carriages, and 70 from mine, which, with the 200 previously fired, made a total of $\mathbf{2 7 0}$ that my mounting had withstood, without the slightest appearance of damage or strnin. Subsequently to the close of the competition, viz., on May 30th, 1865, the tectl of my training racks were tested by lifting up $250 \mathrm{lbs}$. shot, and letting them fall, and passed through this ordeal with credit, as also did the training machinery when tested against tackles on the same day by the Committec.

My gun-carriage was fitted for training, either with tackles (see Fig. $1 e$ and $f$, plate xxix), by single chain (Fig. 1 and $1 a$ ), or by rack and pinion (Fig. 1, plate xxvii).

I think the aboro is a fair statement of what took place, but the Times newspaper, immediately after the trial, considered it probable that neither plan would be adopted as a whole, but that the best features of each would be improved upon, and the Times reporter was right.

The Gun-carriage Committee recommended the adoption of racers of similar size and.width with mine. They also recommended my box-girder form of carriage, and trucks nearly approaching mine in size, and similarly coned, with my running-in and -out gear; but accepted Sir WVilliam's compressor as an improvement on mine, doing away with the inner breeching, which is, $\overline{\mathrm{I}}$ think, the safeguard of his compressor, and one of its most valuable parts. His elevating gear, and his modifications of my compressor are, hawerer, to be reversed, and rollers and trucks of the size used by me, but attached, or rather detached, in the mode employed by Sir WV. Armstrong, are to bo adopted; the position of the lever which secures the elevating gear from running down is to be changed; my running in- and -out gear is to. be employed, but is to be caught in an untried manner; and various amalgamations in the bollards and transporting irons upon the slides are to be made, "and this amalgamation is to be called "The Committee Carriage."

I have now brought the story of the gun-carriages to the present date. If I have dwelt much upon my own difficulties, do not leave this theatre with the idea that I am uttering tho complaints of a disappointed man. Do not think for a moment that I am discouraged. I confidently predicted, when others doubted, that 12-ton guns could be worked safely and with rapidity in a heavy sea. I now predict that when tried in a heavy sea, and with continuous discharges, my vol. $x$. 2 is 
gun-carriage will unmistakeably beat Sir W. Armstrong's, as nell as the amalganated carriage of tho Committee.

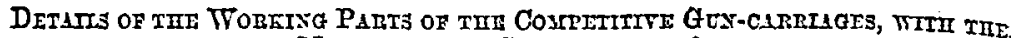 JIODE OF tileir Coxstructioy, \&c.}

\section{Training.}

Training heary broadsido guns by chains secms first to hare been applied on board H.MI.S. " Excellent," in the latter part of 1865.

As fitted there, the purchase ras on oue side of the gun, and the chain led as in MIr. Lynn's plan, the frietion was 'consequently small, and the caso of training rcry much greater than that by tackles, which, as applied in the end of $186 \mathrm{~s}$ to a 12 -tor gun in the "Excellent;" required the full complement of trents-four meu to most the gun slowly.

In the "IInotaur," in December, 1865, Mr. Cunningham led his chain round sheares on the deck, and took the purehase up to the ship's sido to be more out of tho Tay of the other men's operations; but the friction was then considerable; little, if any, adrantage in power was gained over tacliles fitted on the usual plan. MIr. Cunningham's chain is shown in Plate xxix, figs. 3, 3a, and MIr. Iron's, which has a shaft under the deck, in the same Plate, figs. 2, 2a; the ends of the chains in bottr these plans being fastened to the slide. Neither plan requires any lengthened deseription, as the mode of working is apparent, and it is also sufficiently clear from the diagrams that the chains, as fitted to the guns in the two adjoining ports of the "Minotaur," on MIr. Lynn's and on MIr. Cunningham's plan respectively, trere in the Tay of cach other, each chain prerenting the extreme training of the gun next to it. It is likerise erident, that any ehains stretched orcr tho deck, are much in tho way of bringing up powder and shot to the gun.

The morement of these particular chaing, especially the lengthencd one of Mr. Cunningham, and the sudden tightening-either in a roll or in training the gun - of the slack part necessarily left for play, would alwajs bo.dangerous to tho legs of the crew, and probably cause serious accidents to the men carrying up $250 \mathrm{lb}$. projectiles to the muzzle of the $12 \frac{1}{2}$-ton rifled gun. This duty would bo more criti: cal at night, for the meu in a roll might then, inadrcrtently, put their feet arainet these chains for steadiment. If chains be used at all, the least objectionable is probably the straight chain and oscillating pitch-wheel (Plate xxir, fig. 1, 1a), as it does not interfere mith the training of the next gun, is not in the way of the loaders, and is kept stretched in one fixed position upon the deck. The motire power also is clo to the captain of the gun, which would bo of great adrantnge in action when the thick smoke would prerent men at the side from being seen, and the noise, the roice of the captain from being heard. The arrangement of the men pointing being close to the captain of the gun is likewise obtained by my rack and pinion morement, which enables the gun to be trained and kopt bearing upon the object, not only in loading and running out, but also until its discharge.

The epccial adrantages obtained by my rack akd pinion morement were precisely those in which, as Captain Kcy informed the Turret Committee, the turret hid a superiority orer the broadside. Hle stated "that training while loading gave great adrantage to the turret," and afterwards said that, "training by machinery gires the gun in the turret an adrantage;" and in the lecture giren by Mir. Cunningham, in 185., already quoted, he concludes that, "the success, thon, of the discharge of a gan will deperd upon the quick and steady manner it can follow a passing: object," which arrangements, ho belieres, "can only be prorided by the application of steam potrcr."

The tackles used by me were placed and hooked in the same manner as those which rere applied to my iron carriage in the "Research." They are shown in Figs. 1e, 1f, plate xxix, but both chains aud tachles, howerer good for prerenter plans of treining, are inferior means of laying the gun; for the accuracr aimed at in riffed ordnance cannot be secured by their uxe, neither with much motion can the rapid 
touch, often necessary to mako the gun corer tho object, be giren. In the case of tackles, late experience has shown that a sea shipped through port-holes causes mon to drop them and to leare the gun adrift and unmanagcable.

\section{The Racers and Pitots.}

My plan of raised racers, miich had been so much approred in the "Research," was again adopted in the "Minotaur," and the same rucers mere subscquently laid donn in tho "Bellerophon," but in both the latter ships the centres of tho raecrs were let down into the deck three-quarters of an inch, and their ends raised, so as to admit of the gun's being trained round on an horizontal plane. The edge nearest the ship's side of the front raccrs mas slotted to receive a strong hook (Plate xxrii, $\mathbf{D} d$ ), which held the slide eccurely down to tho deck and rendered the gun sceure in any sca. In the "Minotaur," as well as in tho "Rescarch," the front of the slide was further secured by a massiro metal block, working in a groored racer; but after the trial of firing the 12-ton. gun, nincteen times at the top of the roll in the "Minotaur," without this fastening, it was considered unneccssary, more especially as a special pirot-bar or flap of the same strength as the usual cerrice clongated V-flaps had been fitted to the pirot.point in the port as a prerenter.

The adrantage of my racers consisted in their being emploged to hold the slide, and in the power which thoy gave of fastening them, so as to atford the largesi arc of training that could be obtained from the port aperture. They also sizengthened the deck throngh which they wero bolted, and, by means of the flanged rollers on the slide, spread the shock of discharge orer a large space.

In the "Mlinotaur" the gun on my mounting trained $31^{\circ}$ cach may; but no gun with the $Y$-flap and fixed pirot obtained so much as $29^{\circ}$.

A similar result was obserrable in the "Bellerophon" where, althongh the port was closed up from $2 \mathrm{ft}$. Oin. to $2 \mathrm{ft}$. lin., the training was still $31^{\circ}$ cach way. The training of the other guns in a $2 \mathrm{ft}$. 9in. aperture mas only $30^{\circ}$.

In the diagram (Fig. 1, plate xxix) is shown the filling up of the "Minotanr's" port, which was closed on the lower side 1.1 inches, the corners being rounded and made much ligher. The application of this important feature of my system of mounting liad a similar effect to throwing the lower port-cill, a mean of 16 inches bigher out of the water, thus adding greatly to a ressel's capabilitics of fighting in a scaway.

In the. "Bellerophon" the ecntre of the lower port-cill was filled up 7 -inches; and the corvers closed in the same manner as in the "Mrinotaur." With this ar: rengement about $11^{\circ}$ of eleration wero obtained by firing with the gun's muzzle above the port, and $5^{\circ}$ of depression with the muzzle clear of the filling-piece on the lower port-cill.

IInd a small half port been fitted, $7 \frac{1}{3}^{\circ}$ of depression could hare been obtained in the "Bellerophon," and $9{ }^{\circ}$ in the "Mrinotaur," when wauted; but as it was, tho cheap rood was knocked awas when, at the last, extrene depression mas given to the gum. While the wcod remained, it was a protection to the loaders against the spray and sea, nor was any disadrantage found, but the contrary, from closing up the port. The rapidity of "fire in the "Minotaur," with the $150 \mathrm{lb}$. ball, being more than double that previously obtained, and the quickness in the "Ifellerophon," with the $250 \mathrm{lb}$. rifled shot, being equally unmatehed.

The Arscnal iron slicle in the "Dinotaur" was placed upon thin and narror macers; only slightly threker than those first used for 12-ton guns: It was held ondy by a single pirot-point on the top of the lower port cell, which was 17 inehes from the deck. This pirct-point was nuch exposed, yet on this the whole security of the gun depended, and upon it the serere ehock of the recoil was concentrated, and tended to clrag away the ship's side fiom the armour plates allixed to it.

In the "Bellerophon" the rucers were considerably thicter, but were slill nct utilised for holding the slide, or bearing any portion of the sudden shock bachwards occasioned by the discharge of the gun. The pirot-point was, Lowever, better gupported and protected, the port-cill corcring it, and reaching up to a leigit of 20 iachos abore the deck. 
Sir T. Armstrong's slide was supported upon similar racers, but had an additional racer under the fore-end of the slide, which secmed not to be an adrantage in training; like that of the Arsenal, it mas held by a single pirot-point. The usual elongated pirot $V$-flap was used to fasten both the Arsenal and Armstrong slides to this point in the port-cill, and mas in both cases found to be much in the way of the men loading the guns. The eccentrics first used upon the improved Arsenal slido tried in the "Research," were alike applied to these slides and carriages.

In training the slides, the defect of their always dropiping the breech of the gun on slacking up and remoring the eccentric lerers before firing, and of generally letting it slip to the right or left, was obscrable, and the inability of using the slideeccentries to lift the slide when the gun was run in, was a further drawback to their usc. The dischargo of tho gun also frequently upset these eccentrics, and pat them out of rorking order.

\section{The Elerating Gear.}

My arrangement consisted of a screw working through a box, fitting inside another box, which was fastened to the gan. These boxes had a washer interposed between their surfaces, and the outer box mas open at the bottom; henee when the gun was fired with its muzzle abore the upper port-cill, the outer bor lifted sereral inclies up from its resting-place on the inside box rhen the muzzlo dipped under the port-cill, and then dropped easily down again upon the washer on the top of the inner bor. By this contrirance tho weight of the brecch of the gun was receired without any damaging shock, and the jar of the dischargo was likewise absorbed. Any fixed eleration could also be giren and maintained with certainty in bombarding.

Motion was communicated to the scrow through two berelled wheels, suitably supported upon the bottom of the carriage, by means of bandles rorked upon cach side, an arrangement which enabled a rapid touch to be giren to the eleration in case the captain of the gun found that in rolling up or down, his sights nould not come on with the object to be fired at.

The Arsenal elerating gear was somewhat more complicated, and consisted of a band under the gun, rorked by a toothed rack and pinion, to which motion was communicated by means of gearing on the upper side of the carriage. The teeth of the rack being of braes, soon gare way, and the whecla became broken by the jar of firing.

The Armstrong clerating gear consisted of a similar rack and pinion, but of greater size, and of wrought iron. The lerer for securing the eleration was on the lower sido of the pinion, and, falling from the shock of firing, allowed the breech of the gun to more from its position.

In firing with the gun's muzzle abore tho port, the band was slackened from the gun; hence although the gun could be fired in this position with its brecch resting upon the bottom of the carriage, a marked quoin or other means would have to be employed to gire any intermediate and high eleration, which required the muzzle of the gun to be abore the port. Tho shipping and unshipping of the lerer elerating handles before firing was also found to be disadrantageous.

\section{Running-in and-out Gcar.}

My gear consisted of two endless chains, stretched orer two pitch wheels on cach side of the slide, with a screw arrangement for tightening the chains. When the gun was required to be run in, the outside part or toes of the compressor-lerers wero pressed against the lower part of a bos (Figs. $1 \mathrm{D}$ and $C$, plate sxvii), which was serrated on its upper edge, so as to fit between the pins of the chain links, and press them up against the serrated edge of the upper box.

By this means sereral of the pins of tho chains are securely held by the whole force of the compressor, and as both parts of the box which clutch them, are attached to the carriage, it is only necessary to turn the purchase at the rear end of the slide, to draw tho gun in or out. When either operation is finished, the handlo of the 
compressor is turned, and the inner part or heel of the compressor lerers then perform tho mork of compressing.

Thus ono compressor performs the double duty of holding the gun on recoil, and of clasping the cliains on both sides of the slide together, with equal certainty and sceurity; and this gear, being alwajs in place, and out of the way of erery other working part, was at once adopted, as orercoming the chief difliculty previously experienced in working heary guns.

The Arsenal gear also consisted of tro chains of insufficient strength, which had to be caught by hand-lerers, worked independently on each side of the elicie. Tho result of this arrangement ras, that the men were unable to work together, and the etrain being generally borne by a single chain, soon broke one of them.

The Armstrong gear can be best understood by a reference to the cliagram, Figs. $\Delta$, $B, D$, plate Ixriii. The running.in gear completely tired out the men, and hence during the competition, the gun wras loaded at the point to which it recoiled, the men not unfrequently standing out on the port-cill to put in the porrder and shot. IIad there been much rolling; or any sea running, the men could not hare loaded in this position; and eren in this smooth water competition, it was attended with some risk. The running out was performed by tackles in the usual manner (sec Fig. $A$, same plate).

\section{Rusuing in and out-" The Eccentrics."}

For Scott's carriage, eccentrics which had a stop to allow them to pass the centre and remain fired in that position, were derised. This prevented the necessity of the men's holding on to them in runniug in or out; but the arrangenent also allowed the crow on each side to hold on by the ropes which were attached to the ends of the lerers of the eceentries, if required, and so keep the eccentrics ready to drop the carriage off its rear rollers or trucks.

The levers which work the eccentries nro upon the sides of the carriage, and as fitted would prerent injury to the crow in case of the gun going off in running out. Should the eccentries be slacked up, the carriage would drop upon the slide, with a surface of rood ererswhere touching a surface of iron, as dropping the rear of the carringc, lifts the front trucks off the slide; and as both these surfaces are rough, there would then be an absence of sliding suflicient to keep the carriage and gun from moring in a roll. The lerer handles are fitted with bands round the drumliead of the eccentrics, which hold them securely when the lerers aro let drop out of use.

In cousequence of these arrangements, erery moring part of the mounting is in place, ready for use, and No.1, haring no mechanical labour to perform, can give his whole attention to keeping the gun pointed upon the object, which can be done by means of the rack and pinion, so steadily as not to interfere with the loading. The requisite eleration, in case of a change in the heel of the ressel, can also be giren with the same ease and steadiness, and all these operations can be performed simultaneously.

In the cridence taken before the Turret Committec, Captsin Porell speaks of the captain's undivided attention being giren to the "pointing," as an adrantago of much ralue to the turret.

Tho Arsenal carriage eccentrics, both in the "Minotaur" and "Bellerophon," are those now adopted into the eerrice in the place of the Gordon eccentrics and lerers, which had been so long used with revolving slide carriages, and which were also applied to broadside slide carriages until after the trial of the "improred" carriage on board the "Research" in June, 1865.

The Gordon levers, shewn in Fig. 1, plate $x x r$, were morked by the side tackles in ruming out, on slacking which, the carriage dropped off the cecentrics upon its blocks.

The Arsenal cecentrics aro worked by lerer-handles at the rear of the carriage, which compel Nos. 1 and 2 to go out with the gun, weighing down upou the handles with all or nearly all their strength. This work necessarily takes the captain of the gun (No. 1) from other duties, and obliges him to seck for his object, after remoring and handing to another number his lerer-handspike. In case of the gunj going of 
while ruming out, Nos: 1 and 2 mould fare badly. Such an accident happily did not happen, but during the compctition in the "Minotalu" one of the 12-ton guns went off just as the captain was lajing orer the brecch and pushing the priming-tube into the rent. The fact of his touching the gum with so much of his body bent orex it probubly sared his life, and allowed him to escape with merely a eerere shaking.

The Armstrong carriage was fitted with similar cecentrics to those of the Arsenal, but they were more difficult to work, owing to there being no platform for Nos. I and 2 to walk out upon (Plate xxviii 1 ), for neither the tops of the iron plates gntrotituted for wood baulks nor the top of the slide afforded a safo foothold. It is, I think, doubtful whether, in case of dropping the eccentric lerers in a roll, the currixge would remain efationary, for its iron bottom rould rest only upon a slippery iron fide.

\section{The Compressors.}

Scolt's carriago is fitted with two compressors, under the idea that, howerer powerful and strong the rorking part may be, it is not safe to bo dependent upon a single part. Rererting again to the important eridence giren before the Turret Conmittec, Captain Precdy mentions the "great risk of trusting to ono thing in a ship," and this was the riew taken in constructing Scott's carriage, and therefore a second means las been prepared for performing erery important operation for working the gun.

Tho fore compressor (Plate XIT, fig. 2c) is the more powerful of the two compres. sors, being placed on a bigher lerel than the other; the upper lerer arms are longer. The shaft upon which these arms work, passes through each side of the camiare and projects beyond; it is prorided with a right aud left handed serew, to which motion is giren by tuming a handle ehipped upon the shaft at either side of the gun, and thus opening or closing the lerer arms. This compressor is applicd when extraholding power is required, and is useful as an additional means of readily checking the gun when ruming in or out in a heary roll.

The rear compressor being on a lower level than the epare one, and being-also considerably below the level of Scott's proposed height of lower port-cill, would probably escape injury were the front compressor to be hit. Althougli the rear compressor is the less porrerful, it is more importint than the other, being employed to catch tho chains in running the gun in or out, and being also the working compressor for holding the gun on firing. The only addition made to this compressor, to enable it to perform also the duty of cluteling the chain, consists in small pieces or tocs on the outside of the lerer arms. These additions aro-seen at Fig. 1C, plate xrrii, where tho compressor is shenn in scetion "compressing" the baulks preparatory to firing, and consequently with its toe-pieces clear of the lower box, the action of which has been already described under the head of "running-in and -out gear."

The baulks of mood upon which the compressors act are slightly tapered longitu. dinally tomards the front of tho elide, and are rery much tapered in their depth. The object of this is, to allow the gun to more casily at first, from the compressors being slack, so that the sharp ribratory shock wlich would otherwise be giren to the mounling is aroided, and the gun gradually arrested by increased friction, the whole of its monentum being ttilised in the process. This result is much aided by the iron plates which pass between the interstices of the baulks in the slide being thicher at the bottom than at the top, so that, on the gun's discliarge, they act as inclined planes to wedge the carriage closer down upon the slide and its baulks; and hence the desirable combination of the best properties of a holding-domn compressor with that of a gradual and casy absorption of recoil, is atiain:?

There is pactically a multiplication of power in this arrangenent, for when by turning the compressor-handle a pressure of $1 \mathrm{lb}$. is brought against the outside of one baulk, the same force is exerted at each of the other fire surfaces, making a total of $6 \mathrm{lbs}$. for frictional purposes.

The Arsenal compressor arrangement in the "Bellerophon" (Fig. 9, phate Irri) diffored from mine in the shaft being cut into two parts, which thres a rery heary strain upon the sides of a carriage, already too rreak to bear the shock of the discliargo. "The baulks were of wood, but without taper, and in firing, as tho gun warned, it recoiled with much forco upon the breccliug. 
The Armstrong compressor shaft was also in two parts, having on the one side a screw with 2 lerer upon it, to regulate the amount of compression, and upon the other another screw of coarwer pitch, haring a handle or lerer to compress rith, before firing the gun (Plate Ixriii, fig. O).

In case of the proper gun number omitting to pull this handle down, and so pat on the compression, the lower part of the handlo was caught by a projecting piece upon the slide, which pushed it down into place on the gun's recoil, and thus pre. rented the recoil of the gun, with a slack compresaor (Plate Ixviii $A a$ ).

It has been already mentioned that Sir William's compressor baulks are of iron, and hence on the screwing up of the compressor by the self-acting arrangement, a check is necessarily giren to the carringe, which may bo found to hare a more damaging effect upon its slide than the usual tight screxing up of his compressor by hand before discharge.

\section{Construction.}

The Armstrong silide is of double T-plate iron, and open at rear, but to prevent the carriage from running of the slide should the usual outside breeling carry arfar, it was furuished with an inner breeching, fastened, to the slido and passing round, and supporting a strong wooden block, sliding in a groore. This block is placed close against the iron beults in the slide, and serres the further purpose of aiding the compressor, for in case of the gun's reçoil is not fully arrested, the block receires the shock, and, yielding, pushes against the breeching, which stretches gradually, and arrests the gun.

The carriage is of the bos girder-form.

The Arsenal slide is of double $T$-iron, and the carriage single-sided, as shom in the scetions upon Plate sxis, figs. $2 c$ and $d$.

The carriage in the "Minotaur". mas made in imitation of the wood pattern, with blocks across the bottom, \&c. The carriage in the "Bellerophon" had an iron plate bottom.

Scott's slide is of the bor-girder form (Plate xrix, figs. 1b, 1c); the end is closed. The carriage is of similar construction, and fitted with mood on its lower portion, preciscly like the one tried in tho "Researeh." Sec sections, fig. $1 d$.

The slide in the "Research" nas of double T-iron, supported by thin plate iren riretted against it, and its end was closed.

\section{American Compreseors.}

It now only remains to describe Fricsen's turret compressor, and the disc co:preasor which he lias applied to brosdzido guns.

The shaft of Ericsson's turret-compressor does not pass through the carriage, it has a single screw thread upon it, and tho plates which are attached to the bottom of tho carriage pass between four baulks, echich rest spor the botlow of the turret. Ali these baulks are free to more laterally, and are parallel. The carriage is alnass upon its rollers, with its bottom plate clcar of the baulss, and therefore its momentum is not uscd up for reducing recoil; this, there is only the single cenpressor worked on onc side to check, and the result is, that the conipressor cannot be unscrewed after firing without great difficulty, and a delay of two or three minutes. In tho "Irintononol," the action of these compreseors was far from satisfactorg, although the charges were small.

The disc-complessor has been too rocently introduced into America to lare had much trial, but so much doubt seams to exist there as to it 3 holding power, that air and. water are both under consideration for we in cylinders to bo placed under the slides for broscleide guns to abeorh tho recoil.

\section{Consideratione.}

I wisk to point out that the imost important questions suggested by this afternoon's looture for your consideration are- 
1st. The description of gun-carriage needed; whether it should be entirely of iron, and singlo sided, regardless of tho ribration; or whether, for strength and durability, it mould not be better to hare double-sided carriages filed with wood to absorb the ribration.

2nd. Thether the heary guns of the present daj can or eannot be worked by the Eame means used for light guns a century ago, and whether it is not high time to arail ourselres of such inechmical appliances as will, with fewer men, enable us to handle the 12-ton guns with greater ease, and to uso them more efficiently than was crer achiered with the long 24-pounder of 1805 .

3rd. Whether the various compressors I lasre described indicate that we are in the track which will ultimatels lead to the desired goal. In considering the matter I would request your attention to this, all parallel and side-plate compressors on parallel slides, such as that of Sir W. Armstrong's and the Arsenal, are, in my opinion, really non-recoil appliances, inasmuch as that compression and friction cleck tho recoil, and then the force of recoil, which is in excess of the power of the friction, must be orercome by leverage compression; the blow, which is thereby delirered upon the slide and deck, must be sudden and destructive, but with tapered banlks and redge plates, there is not only compression and friction, but the resistance of inclined planes to absorb the recoil, and that therefore much less leverago compression is needed.

The Crampux : Any questions that may be asked, Captain Scott will now be linppy to answer them.

A IIEJSBER: I should like to know a little more about the rumning-in and runningout and the elerating gear.

Captain Scort : Diagram (sce Plate, xxrii, fig. D) is an excellent drawing, which will, I think, show clearly how the running-in and out gear is fitted. I shall be happy to describe further tho elerating gear, after hearing if there are any more queries. -

A Mescen : Do you nse a ropo sponge?

Captain Scotr : No. I raiso the lower half port as much as possible, and in the erent of haring to close the upper half port when the ship rolls, the gun should be loaded through a small scuttle, which should be cut for the purpose of letting the cnds of the rammer and eponge stares pass through.

Captain IIEATHorx, R.A. : When jour gun is at its greatest eleration, do you find any great strain on the serew gear with which jou elerate it?

Captain ScorT : No; it was notieed that the gun jumped about rery little, when fired with its muzzle considerably abore the port, the breech being down upon the carriage. The gun gires $11^{\circ}$ in this position, but a new carriage might easily be arranged for $16^{\circ}$. At the time I commenced my carriage it was affirmed that more than $9^{\circ}$ of eleration were unnecessary.

Captain HEATHOBY : What amount of depression?

Captain Scort : The depression allowed by the wooden chocks with which the

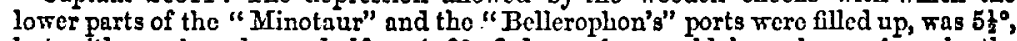
but with an iron lower half port, $9^{\circ}$ of depression could have been given in the "Mlinotaur's" port.

Captain Hestrions: What I wanted to know was to what extent of depression has the gun been already fircd, so as to test the screw?

Captain Scorr : $7 \frac{1}{2}^{\circ}$. Do you wish me to further describe my clerating gear?

A MLEMDER : Sir William Armstrong's.

Captain SCOTT : Sir W. Armstrong's consists of a band under the gun, working in Elots on the inside of either bracket of the carriage, motion is giren to this band by a rack and pinion, which, as the gun has no breech preponderance, raiscs it rapidly, the only delay being that of getting the lever handspikes into their sockets, and in clamping and slacking the stop, or paul arrangement. In case, however, further elevation or depression is found necessary, the captain must wait till the handspikes are again re-shipped, the proper cleration giren and the pinion clomped, and the handepikes remored clear of the carriage, before he can fire the gun. As the elevating and training are both inrolred in pointing the gun, I may mention the disadrantage of training with 
tackles. In caso of the ship's heeling orer, the lee guns will hare a grent tendency to swing in towards the lec side in consequence of the slope of the deck, and to train the gun you hare to send the crew from one side to the other; whereas with machinery you have sufficient power to train the gun at all times, retaining the gun numbers on their proper sides, and thus confusion in the dense smoke and excitement of an action at close quarters rould be aroided.

The Crismusax : You hare stated the relatire number of men in the firet cxperiment. What were the relatire numbers in the last competition?

Captain Scotr: 14 men at my carriage in the "Ifinotaur," and 16 men at the other earriages; there were 16 men at all the carriages in the "Bellerophon"this number of men at my mounting being only required for hoisting-up, carrying to the gun, and loading the 250 . Ib. clongated shot.

Tho Charras : How many were necessary for the gun-carriages, apart from the question of shot?

Captain ScoTT : Loading with the round ball jou could work my gun-carriage with four men, and do so rery easily with six men; but the other carriages in the "Bellerophon" were trained with tackles, 16 men would be, in any case, requisite for them.

A MEsrber: Did jou fire round shot as well as the elongated bolt?

Captain ScorT: We fired no round shot in the "Bellerophon." We fired round shot in the "Minotsur ;" the round shot were 150 lbs. weight, the elongated shot $250 \mathrm{lbs}$. The former were lifted up to the muzzle and then rolled in rery easily; the latter had to bo got up perfectly horizontal, and then the studs bad to be accurately adjusted to the groores of the gun.

A MEsiner: Was the ship rolling when jou run out jour gun in ten seconds?

Captain Scorr : No; but the rolling would not hare stopped it; there is suffcient power in the purchase to run the gun out with the ship heeling over considerably.

A MEMBEs: Will you describo your training apparatus?

Captain Scorr : The training apparatus is simply this-there is a ehnft under the: gun which carries two pinions working into a scparate toothed rack under the fore. part of the slide, and into a second toothed rack cast in one piece rith the racer under tho rear. This shaft is turned by a single whecl, or else by two handles (both are fitted) at the rear of the slide.

Admiral RxDER: What was decided as to the adoption of Jour's or Sir William Armstrong's carriage?

Captain Scotr : The Committeo said, I beliere, that they and therefore, as it was recommended to make the carriage by contract at Elswick, that Sir William's should be adopted.

Captain SELwY, R.N. : Thero is ono observation which $I$ should mish to make, in order that, as $I$ ece an engineer and mathematician present, he should not go aray with a falso idea of what Captain Scott stated in his paper. He was speaking of the one pound applied being distributed as one pound on each surface. I did not understand that he meant that one pound was distributed upon each surface. You may increaso power by sacrificing time, but you cannot make one pound exerted orer one minute, any more than one pound exerted orer one minute.

Captain Scotr: I kas speaking of it as a frictional poker. I did not mean a multiplying power.

Professor O. Braxe : This is the question: that the nood that Captain Scott spoke of receires all the force and passes it forwards. Ile does not mean that that wood does any more than iron; but it passes the force applied orer the parts equably; whereas the iron passes it by a rebound, a shock. The one receives it, swallows it, pases it; the other reccires it and returns it, which -causes mischief. I think Captain Scott is perfectly right in his explanation, although not esactly matheratical.

Captain Scorx: It was not certainly mathematically expressed. I carefully guarded myself against using scientific terms, and, thercfore, did not go into co-eff. cients of friction, \&c.

Captain SeLwrs: I was only ansious that no one should go aray from this Insti- 


\section{JODERN OARRIAGES FOR HEAVY KAVAL ORDNANCE.}

tution with a false idea which might lare arien from the words used. I can only add my testiwony to the rery brilliant results which Captein Scott has shown us, and the great pleasure with which I have always listered to.his rery comprehensire and sound lectures on the subject of artillery gencrally.

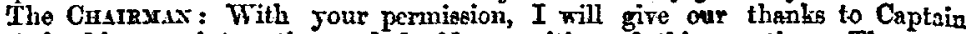
Scott for his rery interesting and lucid exposition of this queetion. The great merit appenss to be in the simplicity and the security, which his plan scems to me, entirely to cmbrace. I can well understand why the preference was giren to the other carriages, although at a glance it appears to ne it was not necessary to hare any compctition. But I bare obserred, strange to say, that whatever is more ingenious is that which is adopted. And though it maj soem strange to say so, I hare obserted, with respect to inventions, that they generally adopt the most ingenious and lenst practical as the best. That is the only way I can explain the case with respect to the carriages, and with respect to the guns. I do wish Captain Scott every suecess in this matter. I think he is entitled to immense credit for the persercrance with which he has worked out this question. It is quite erident that his plans hare been clearis beforo his mind in the first instance, and hence he would not be put off his course by the constant dificultics which hare been thrown in his way. 